\title{
Rевевсн автіске: Participation of farm women of Assam in cultivation of rice and problems faced by them
}

Doree Saikia

Article Chronicle: Received :

06.06.2018;

Revised :

01.07.2018;

Accepted :

16.07.2018

KEY WoRds:

Participation, Farm

women, Problems
SUMMARY : Women are the backbone of agricultural workforce also and make essential contributions to the agricultural and rural economies in all developing countries. Compared to men, farm women are generally involved in a wider range in crops, livestock and agro-based activities. Women are usually employed in most difficult field operations like sowing, transplanting, weeding, intercultural operations, harvesting, threshing and agro- processing. Though women plays an active part in agricultural activities but they faced lots of constrains. Thus, the present study was conducted to find out participation of farm women of Assam in cultivation of rice and problem faced by them with the following objectives to find out the background characteristic of farm women, to study the participation of farm women in cultivation of rice and to determine the problems faced by the farm women in cultivation of rice. The study was conducted in six districts of Assam. A purposive cum simple random sampling technique was adopted for selecting the respective samples for the study. Altogether 1500 farm women were selected for the present study. Data were collected personally by interview method. The findings reveals that more than fifty per cent of farm women contributed labour independently in areas such as cleaning $(55.17 \%)$, transplanting (55.08\%), harvesting (54.75\%), winnowing $(51.08 \%)$ and drying of grain $(50.16 \%)$. And the problem faced by the farm women in cultivation of rice were lack of knowledge on plant protection ranked I followed by lack of irrigation facility ranked II, and lack of need based training ranked III.

How to cite this article : Saikia, Poree (2018). Participation of farm women of Assam in cultivation of rice and problems faced by them. Agric. Update, 13(3): 350-354; DOI : 10.15740/HAS/AU/13.3/350-354. Copyright@ 2018: Hind Agri-Horticultural Society.
Author for correspondence :

Poree Saikia

Department of

Extension and

Communication

Management, College of

Community Science,

Assam Agricultural

University, Jorhat

(Assam) India 